OPEN ACCESS

Edited by:

Sergio Ulgiati,

University of Naples Parthenope, Italy

Reviewed by:

Paul Dewick

Keele University, United Kingdom

Yiming Zhuang,

lowa State University, United States

*Correspondence:

Sherwat E. Ibrahim

sherwat@aucegypt.edu

Specialty section:

This article was submitted to Urban Resource Management, a section of the journal

Frontiers in Sustainable Cities

Received: 21 August 2019 Accepted: 12 August 2020

Published: 16 October 2020

Citation:

Ibrahim SE and Sarkis J (2020)

Technological Innovations and

Degrowth Opportunities From Urban

Egypt: Initiating the Discourse.

Front. Sustain. Cities 2:492866.

doi: 10.3389/frsc.2020.492866

\section{Technological Innovations and Degrowth Opportunities From Urban Egypt: Initiating the Discourse}

\author{
Sherwat E. Ibrahim ${ }^{1 *}$ and Joseph Sarkis ${ }^{2}$ \\ ${ }^{1}$ American University in Cairo, School of Business, Cairo, Egypt, ${ }^{2}$ Worcester Polytechnic Institute, School of Business, \\ Worcester, MA, United States
}

Degrowth can support urban sustainability, especially in the Global South. Degrowth and technological innovation have a controversial relationship, some believe they cannot function together, others believe they are supportive. This debate is evaluated and we posit that they are compatible if managed carefully with effective policies in place. We provide three technological cases from Egypt, where these cases are mapped to degrowth elements. This study is just an initial step in introducing the discourse; degrowth with environmental and social sustainability needs to be included on the map of policy makers. Policy implications include investment, awareness raising, education, and diffusion of technologies that can support degrowth.

Keywords: technological innovation, degrowth economies, urban management and governance, sustainability, Egypt

\section{INTRODUCTION}

Ecological modernization theory speculates that technology and modernity can support the decoupling of economic growth from environmental degradation (Spaargaren and Mol, 1992). Although this theory is not without its detractors (March, 2018), there are potentials for technology and innovation to contribute to decoupling by providing the necessary quality of life, with even less growth. There are also possibilities for these technological innovations to occur in impoverished and vulnerable regions of the world.

In this policy brief, we examine cases from the Global South ${ }^{1}$ using examples from the urban regions within and around Cairo, Egypt. We posit and show examples of various technological innovations that can improve urban sustainability-on all dimensions-while supporting a degrowth environment. We are not proposing that technology is the only solution; behavioral change and acceptance of these innovations will also be critical. Creative solutions are needed, given the increasing rates of urbanization and poverty existing in developing country urban settings. We do believe technological innovation can and should play an important role. It is with this perspective we present this short perspective and policy brief paper.

We begin with a brief description of degrowth, which sets the stage for the overall goal for building "strong sustainability" in the urban developing country environment. We build on the degrowth background by reviewing its coupling relationship with urban sustainability and technological innovation. Some initial cases of technological innovation in Egypt's urban

\footnotetext{
${ }^{1}$ The phrase "Global South" refers broadly to the regions of Latin America, Asia, Africa, and Oceania. It is one of a family of terms, including "Third World" and "Periphery," that denote regions outside Europe and North America, mostly (though not all) low-income and often politically or culturally marginalized (Dados and Connell, 2012).
} 
setting that have potential to contribute to degrowth is presented; a summary of degrowth elements addressed by the innovation is also included. Based on this background and initial case observations, some policy implications are discussed.

\section{DEGROWTH}

The degrowth movement has seen multiple perspectives and is not a monolithic movement itself.

Degrowth has been defined as downscaling production and consumption to improve planetary well-being, ecological conditions, and equity (Schneider et al., 2010; Kallis et al., 2018). It has been purported to be a countermovement to ecomodernism (Grunwald, 2018) with a pursuit for alternatives to capitalism that cultivate human flourishing (Krueger et al., 2018). Theoretically, it supports voluntary, smooth, and equitable transitions to localized economies with equally distributed resources through democratic institutional forms.

Degrowth calls for a future where societies live within their ecological means; with shrinking economic systems providing greater space for human and ecological ecosystems. This philosophy and movement has initiated a broader sustainability debate that considers population, technology, and lifestyles alongside social justice, democracy, and quality-of-life (Kerschner et al., 2018).

Degrowth advocates seek out practices and systems to reduce resource use levels. Notions like efficiency and sufficiency are important philosophical mantras within degrowth communities advocating for this goal (Hobson, 2013; Jarvis, 2019). Efficiency relates to using the least amount of input to achieve the highest amount of output, and sufficiency indicates all that is required with the smallest amount needed.

There is also a philosophical role for technological innovation. By disconnecting from larger systems, innovations for degrowth need not focus on technology for technology's sake. These advocates seek to target new social and technical arrangements, enabling a convivial and frugal anthropocentric existence (Kerschner et al., 2018).

Even with these admirable degrowth goals and philosophical elements, degrowth feasibility and practicality remain major barriers. Guaranteeing these high ideals is a challenge that requires a persistent reduction in resistance, while maintaining pressures and motivation. Whether these institutional perspectives are driven externally by developed nation idealists, or grow naturally from developing nation groundswell and institutions, it is a long-term tension.

Given the greater urbanization occurring throughout the world, what is the role of degrowth in urban environment and sustainability situations?

\section{DEGROWTH AND TECHNOLOGICAL INNOVATION-TRANSFORMATION OR TENSION?}

Cities may contrapositively be the locus of sustainability problems and a location for sustainable solution emergence
(March, 2018). Urban-city-metabolism, with its material and energy flows, is a complex laboratory for natural and human systems interactions and interdependencies (Restrepo and Morales-Pinzon, 2018). Studying the resource metabolism of an urban system and the internal dynamics of resource exchange among city components is essential (Ulgiati and Zucaro, 2019). Information and communication-technological-innovations can greatly influence urban metabolism, while contributing to degrowth goals.

Nascent urban sustainability research has started to consider reductions in urban system and sub-system production and consumption (Jarvis, 2019). This research posits using nontraditional stakeholders to support structural changes in participatory urban governance. It also supports learning from small-scale community initiatives. These smallscale community initiatives include feasible and accessible technologies for urban communities, especially in urban developing nation environments.

Technological innovation is the act of introducing a new device, method, or material for application to commercial or practical objectives (Schilling and Shankar, 2019). Technological innovations from small-scale community initiatives have the potential to play an important role in urban sustainability and degrowth. The transformative and disruptive role of technological innovation-if developed and applied thoughtfully-can contribute to addressing strong urban sustainability concerns-sustainability that is broad, equitable, and generational.

Degrowth has seen conflict between technological skepticism and technological enthusiasm (Kerschner and Ehlers, 2016). Much of the degrowth community is circumspect when it comes to technology-it is a basic philosophical tension. There is an argument that urban technological innovations have underlying capitalist system undertones or post-capitalistic characteristics (Batty, 2013; Gibbs et al., 2013; Garcia et al., 2018; March, 2018).

Critical degrowth scholars point to technology as supporting neoliberalism that justifies techno-authoritarian market solutions (Latouche, 2009; Romano, 2012). Sustainability technology that promotes profit and efficiency especially has capitalistic treadmill tendencies (Kerschner et al., 2018). They argue that technologies in urban settings-no matter how well-intended-result in goods and services consumption increase, which do not contribute to sustainability (Carvalho, 2014; Hollands, 2015). Their basic proposition is that technological innovation solutions are not appropriate for degrowth, causing greater social injustice.

The corporate and entrepreneurial discourse surrounding smart cities implies that private companies control technology implementation and urban data (March, 2018). The worry of degrowth technological innovation skeptics is that this monopolistic access expresses private-profitability-desires, images, and values rather than seeking the public good and values (Hollands, 2015). Additionally, dependence on highend and complex technologies may require experts to manage them, leading to undemocratic accessibility of such technologies (Illich, 1974).

The other side of the debate includes degrowth technology enthusiasts. Degrowth technology advocates argue that 
technological innovations can lead to fundamental changes in urban sustainability and social inclusion (Smith et al., 2014). Degrowth supportive technology may erode the basic principles of capitalist growth and set out the possibility for a postcapitalist transition (Mason, 2016). Rather than constraining technology, there needs to be an examination of ideologically reorienting technologies to serve degrowth values, such as freedom, sociability, and environmental stewardship (Likavčan and Scholz-Wäckerle, 2018).

Technological innovations can and need to be compatible with urban degrowth transitions as more efficient uses and organization of urban systems (Wiig, 2016) occurs. Greater cooperative and participatory uses of emergent technology is also needed (Hollands, 2015). Urban scholars and practitioners need to find ways where technological transitions into socioenvironmental justice are not dictated by the pursuit of economic growth, and where top-down enforced urban governance models are replaced with forms of localized, grassroots, and politically dissenting participants (Bunnell, 2015). These localized-grassroots efforts are where small-scale technological initiatives can be used to support the degrowth philosophy.

Examples of these small-scale innovations include urban gardening (Anguelovski, 2014), urban water supply (Domènech et al., 2013), and housing (Cattaneo and Gavalda, 2010; Lietaert, 2010). Each can contribute to degrowth.

A number of degrowth elements are supported by these initiatives. For example, the degrowth social justice philosophy of sufficiency is exemplified by localized food production and shared alternatives to private property (Bregman, 2017). Sustainability studies on decentralized and collectively owned renewable energy projects (Kunze and Becker, 2015) and smallscale and user controlled water supply technologies (Domènech et al., 2013) have contributed to degrowth and sustainability.

The technology and degrowth debate should not just target technology. Degrowth-related communities and projects define themselves by low- and high-tech devices like the Fairphone, open source, and bicycle kitchens. Networks of actors, narratives, and rationales require consideration (March, 2018). Particular attention needs to be given when discussing technological innovations related to degrowth because of context-related attributes, such as convivial, that of an atmosphere of friendliness; appropriate, suitable or proper in the circumstances; feasible, possible to do easily or conveniently viable, capable of working successfully; and autonomous, having the freedom to govern itself or control its own affairs (Kerschner et al., 2018).

Technology should service citizens and help produce and circulate knowledge. Information and communication technologies (ICT) are instrumental to sharing economy platforms (Martin, 2016), leading to collaboration and value creation within new economic models (Mason, 2016). The potential democratization of technology and digital participation can benefit social justice (Viitanen and Kingston, 2014). ICT can be used to make urban problems transparent and impact on how we design, produce, and consume at the urban scale (Anderson, 2012).

These approaches can also enhance co-design and coproduction through collaborative and bottom-up experimentation with ICT (March, 2018). Grassroot technologies can target urban problems, such as housing access making homes available to a wider audience (Shelton et al., 2015). These technologies have identified simple, small-scale, and frugal ICT solutions that promote citizen-centric, coproduction, and participatory approaches (Pollio, 2016).

Other innovations, not just ICT, also contribute to degrowth in urban settings. Low-cost, creative, and easily accessible innovations can also contribute. Some of these are necessary for degrowth solutions in developing nations. We now shift our attention from the general technological innovation and degrowth debate and provide some examples of innovations from an urban Global South setting-specifically Egypt.

\section{TECHNOLOGICAL INNOVATION EXEMPLARS FOR URBAN GLOBAL SOUTH DEGROWTH}

Most degrowth and sustainable consumption studies have targeted Europe and North America (Hobson, 2016; Schröder et al., 2019). Focusing on the Global North is understandable given the historical high use of resource levels. However, there is a need to similarly highlight degrowth initiatives taking place in the Global South. These initiatives usually rely on social and technological innovations that are driven by the limited economic options in these regional populations.

Also, there is important synergy to be gained from discussing degrowth and sustainability alternatives in the Global South. Indeed, we must resist falling into the trap of thinking that while the North needs to degrow, the South needs "development" (Escobar, 2015: p. 31).

The following sections provide three evidence-based cases that broach different dimensions and elements of degrowth. The three cases demonstrate widely promoted degrowth values derived from sufficiency and efficiency. In the selection of the cases, we aimed for a mix of high and low tech-dependent innovations that differently address the economical, environmental, and social implications of innovation. The aim here is not to be comprehensive, but rather to establish an exercise on mapping degrowth attributes to technological innovations.

\section{Sustainable Building Bricks: The Case of Bastoob $^{2}$, Egypt}

Most of Egypt's population lives in a narrow strip of land along the Nile Valley and Delta area using $<5.5 \%$ of Egypt's territory. Urban projects targeting rehabilitation in cities nearer to the desert aim to decrease congestion and halt urban sprawl over agricultural land. There is a need to design low cost energy efficient housing in order to attract populations looking to relocate to these regions, especially given the higher cost of living and higher electricity consumption in the denser areas like Cairo and Alexandria (Dorra et al., 2018).

There have been efforts in Egypt to provide sustainable housing to the urban poor and ensure access to adequate, safe,

${ }^{2}$ The authors received permission from Bastoob to publish this case. 
and affordable housing and basic services. Sustainability and low-income housing are better understood through systemic frameworks that build on ecological models for housing solutions and social innovation (Smets and van Lindert, 2016). Holistic proposals should aim for cities and human settlements that are inclusive, resilient, and sustainable, and should include eco-building approaches that depend on building material innovations from local suppliers.

This situation is where Bastoob, a local entrepreneurial firm, plays an important role. Instead of conventional cement mortar construction, Bastoob provides innovative, low-cost, and ecofriendly construction solutions that don't require plastering. The innovative interlocking construction block designed by Bastoob allows for the quick and cost efficient construction of housing units and other buildings. Each brick is constructively designed to lock itself into the other bricks around without the use of cement, thereby significantly lowering the construction carbon footprint. Put together, the bricks are aesthetically pleasing and result in stronger facilities. The building systems has been extensively tested for structural strength and durability, as well as for fire, rain, and sound resistance (Maritz, 2018). The blocks' bearing capacity was determined and verified by the Egyptian National Housing and Building Research Council to be in excess of 23 tons. The blocks are thermally insulating and therefore result in more energy-efficient constructed facilities that are comfortable without requiring large mechanical energy to regulate indoor temperature. In addition to faster construction, interlocking bricks can be salvaged without damage when the house is being dismantled in the future.

Bastoob complements their innovative technology with a socially geared business model. While the blocks are ideal for urban settings, their saving advantages become far more apparent for remote and rural communities. The focus of the firm is on low income housing provision while working within impoverished areas to help improve their quality of life. They help create more jobs with a commitment to providing safe and comfortable working environments for building crews. The self-aligning nature of the blocks are not too dependent on crew skills, so besides delivering the blocks and/or acting as a contractor to construct structures using the blocks, Bastoob happily trains contractors and workers in the local communities to build using these blocks. The fact that the community would participate in the design process and be responsible for construction will not only reduce costs, but can also help build a sense of ownership within the community.

Bastoob is also engaged in ongoing research on initiatives that can help reduce cement content, solid waste, and material carbon footprint. Technical improvements, such as improving construction block thermal properties-keeping heat out during warm periods and cold out during cool periods-are a future advancement the firm plans to add.

Their inclusive model has already allowed them to work with low income sectors-through NGOs-to identify dwelling and facility needs, in addition to partnering with local Egyptian clients to identify energy-and-cost-efficient solutions for urban projects, using efficient labor-intensive construction methods that results in less air, water, and soil pollution. Figure 1

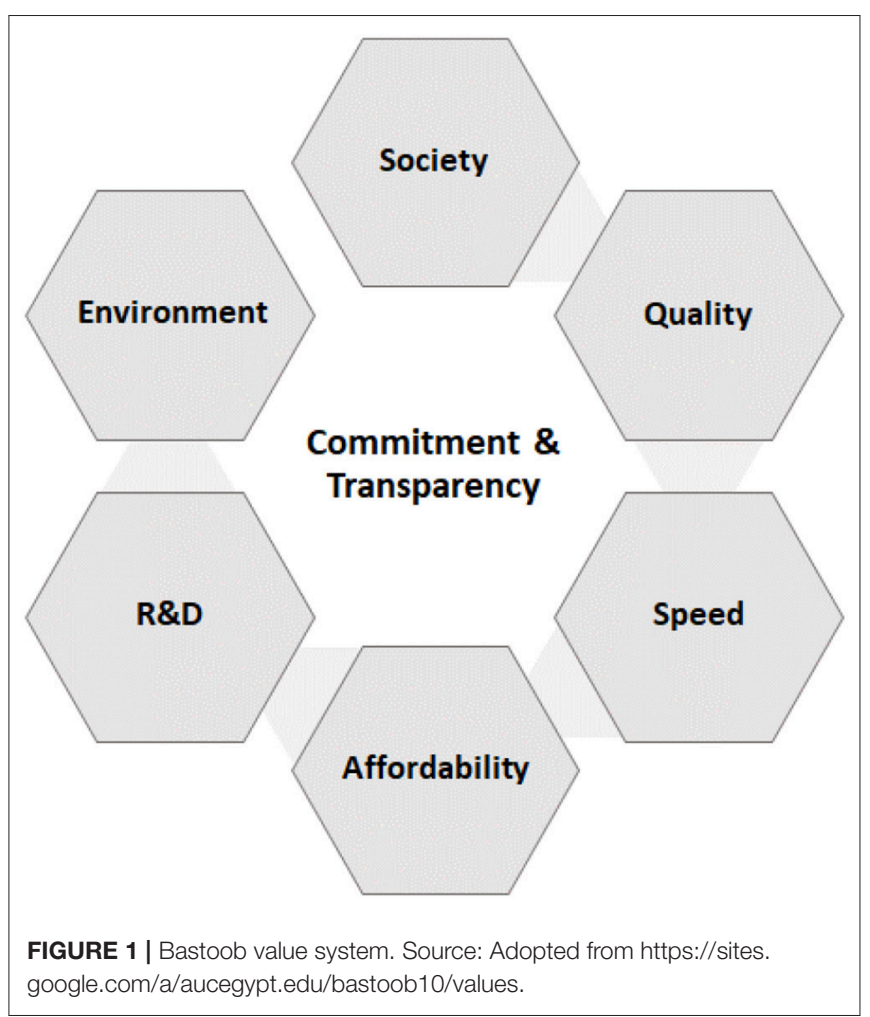

presents Bastoob's communicated value proposition to the local Egyptian market.

\section{Urban Morphology: The Imbaba Agriculture Social Initiative Case ${ }^{3}$}

Informal settlements cover more than $60 \%$ of Egypt's urban area. For example, almost 12 million inhabitants representing $70 \%$ of Cairo's population live in "informal areas" (Rongbo, 2017). This phenomenon began in the 60 s when agricultural land owners started selling their relatively small plots to individual house builders. A lack of urban planning and "densification" in informal settlements of urban Egypt has led to limited green spaces (Attia, 2017). Food security is an increasing concern with urban dwellers living in informal settlements with insufficient incomes to fulfill food and non-food needs (Satterthwite, 2011).

Imbaba is one of the most visible informal settlements in the area of Giza that resulted from fragmentation of agriculture land (Perronnet and Rodemeier, 2010; Tawfic et al., 2018). Horizontal expansion has become impossible with substandard commercial construction resulting in small plots with minimal regulatory conformance (Gouda, 2013). The urban fabric is very compact with tight living spaces for large numbers of inhabitants per family (Gouda, 2013).

This case represents an innovation to retrofit Imbaba's west side settlements into agriculture productive units using frugal technological solutions (Tawfic, 2016). The technology relies on hydroponic systems and develops a community based strategy

\footnotetext{
${ }^{3}$ The authors received permission from Abdallah Tawfik to publish this case.
} 


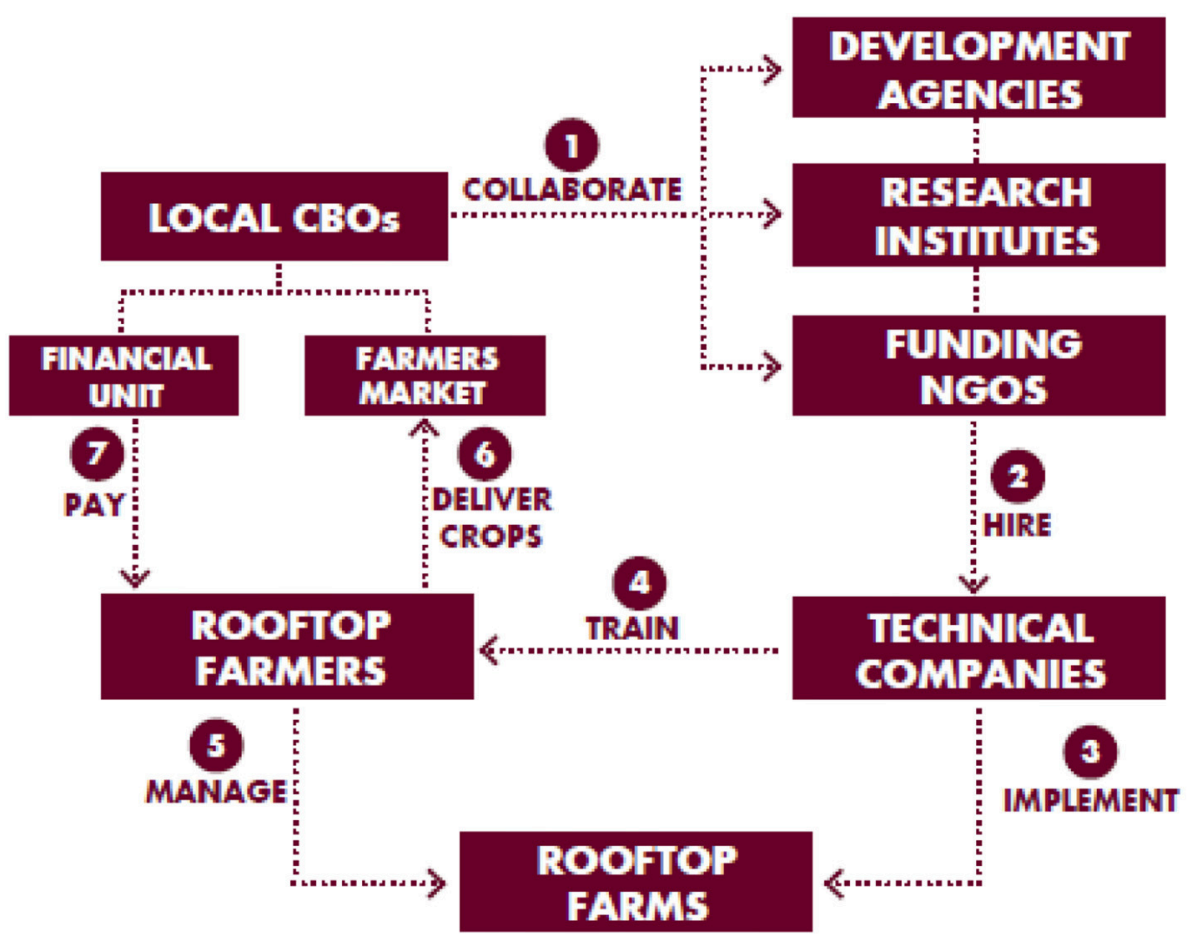

FIGURE 2 | Imbaba's community based project for rooftop hydroponics. Source: Tawfic et al. (2018).

to organize the trade of crops. Hydroponics is a technique that grows plants without a layer of soil. A hydroponics system is relatively light in weight, water efficient, and mobile. They are able to offer superior aeration of plant roots compared to soil based systems (Price, 2013). The plant is usually supported by a thin layer of substrate, while the plant's roots are immersed in a water-based nutrient solution (Nowak, 2004; Quesnel, 2011). Plants may grow 2-4 times faster as they have ready access to nutrients and water, using only $10 \%$ of the water required in soil based systems (Nowak, 2004; Price, 2013). The plants normally soak up the solution, putting their energy into growing leaves, fruits, and stems instead of roots (Nowak, 2004).

The project also has a social enterprise element as it is managed through the collaboration of different localized stakeholders. Imbaba's Community Based Organization (ICBO) acts as the focal point and connects different project entities including rooftop farms technicians, developmental agencies, research institutes, and residents. ICBO leads the selection process of residents who have the potential to fit in the predetermined project criteria and plays an important role in managing the financials of the project. Figure 2 summarizes Imbaba's community based project relationships for rooftop hydroponics.

\section{Lab Equipment Sharing: The Case of Scien-up ${ }^{4}$ Egypt}

A common challenge facing scientific research communities is the ability of scientists and innovators to afford the necessary equipment and maintenance costs for their required technologies. Experimenting costs for new technologies and scientific innovations in Egypt have been clearly outgrowing available funding and resources (Saleh and Ibrahim, 2018). For example, imaging microscopy for research can cost millions of US dollars. Given the high costs and specialization level of scientific facilities, a sharing model is suggested in the case of Scien-up.

Scien-up is an entrepreneurial platform located in Egypt targeting scientific communities in emerging markets in the Middle East and Africa. The scientific communities are mostly associated with urbanized areas. The company was founded to democratize access to essential equipment for researchers and innovators, reduce duplication nationally, and free up scarce resources for other investments. Scien-up's model is driven by "sharing economy" characteristics. It provides access to scientific services and research collaborations by connecting supply and demand sides through an online platform. This platform lists and moderates equipment sharing to target idle resources that could be exchanged between peers.

The concepts of the sharing economy and collaborative consumption encompasses novel ways to connect underutilized resources (Botsman and Rogers, 2010). While much of the recent discussion has been focused on disruptive retail and consumer oriented companies, such as Uber and Airbnb; who may actually be exploitative of lower income participants, the potential for

\footnotetext{
${ }^{4}$ The authors received permission from Scien-up to publish this case.
} 


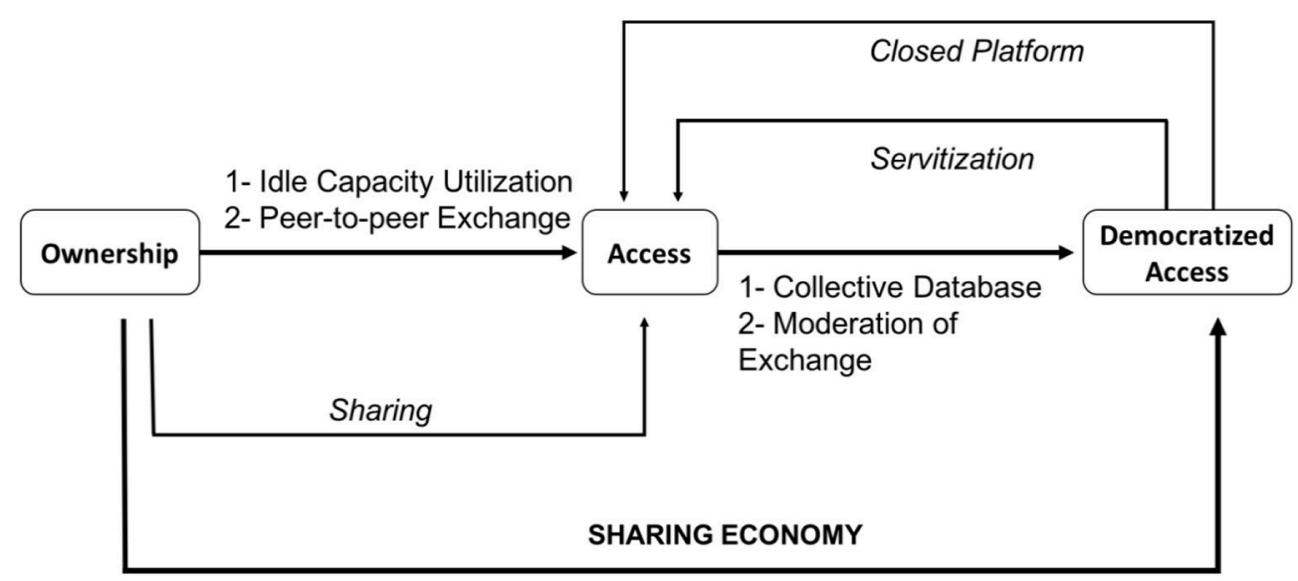

FIGURE 3 | Scien-up: from ownership to democratized access. Source: Saleh and Ibrahim (2018).

TABLE 1 | Degrowth dimensions, elements, and small-scale innovation relationships.

\begin{tabular}{|c|c|c|c|}
\hline Degrowth dimensions & Degrowth element & Can be seen in & References \\
\hline Sufficiency & Disconnecting from larger systems; self-determined path & Urban morphology & $\begin{array}{l}\text { (Hobson, 2013; Kerschner et al., } \\
\text { 2018) }\end{array}$ \\
\hline \multirow[t]{4}{*}{ Sufficiency/ efficiency } & Dynamics of resource exchange & $\begin{array}{l}\text { Lab equipment sharing } \\
\text { Urban morphology }\end{array}$ & $\begin{array}{l}\text { (Hobson, 2013; Ulgiati and Zucaro, } \\
\text { 2019) }\end{array}$ \\
\hline & Collaborative consumption; sharing economy platforms & Lab equipment sharing & $\begin{array}{l}\text { (Botsman and Rogers, 2010; Martin, } \\
\text { 2016; Saleh and Ibrahim, 2018) }\end{array}$ \\
\hline & Localized efficiency; grassroots & $\begin{array}{l}\text { Lab equipment sharing } \\
\text { Urban morphology } \\
\text { Sustainable building bricks }\end{array}$ & (Bunnell, 2015) \\
\hline & Innovative bottom-up strategies; frugality & $\begin{array}{l}\text { Lab equipment sharing } \\
\text { Urban morphology } \\
\text { Sustainable building bricks }\end{array}$ & $\begin{array}{l}\text { (Cattaneo and Gavalda, 2010; } \\
\text { Lietaert, 2010; Domènech et al., } \\
\text { 2013; Anguelovski, 2014) }\end{array}$ \\
\hline Efficiency & $\begin{array}{l}\text { Catalyzed ICT solutions (promoting citizen-centric, } \\
\text { coproduction, and participatory approaches) }\end{array}$ & Lab equipment sharing & $\begin{array}{l}\text { (Pollio, 2016; Likavčan and } \\
\text { Scholz-Wäckerle, 2018) }\end{array}$ \\
\hline Deepening democracy & Realizing equal wealth distribution & $\begin{array}{l}\text { Lab equipment sharing } \\
\text { Urban morphology } \\
\text { Sustainable building bricks }\end{array}$ & (Kerschner et al., 2018; Jarvis, 2019) \\
\hline \multirow[t]{2}{*}{ Defending ecosystems } & Environmental stewardship & $\begin{array}{l}\text { Urban morphology } \\
\text { Sustainable building bricks }\end{array}$ & $\begin{array}{l}\text { (Likavčan and Scholz-Wäckerle, } \\
\text { 2018; Jarvis, 2019) }\end{array}$ \\
\hline & Extending human relations rather than market relations & $\begin{array}{l}\text { Urban morphology } \\
\text { Sustainable building bricks }\end{array}$ & (Gibbs et al., 2013; Jarvis, 2019) \\
\hline
\end{tabular}

sharing economy principles could expand to include sociotechnological models.

Data collected from Egypt's scientific community had shown a dire need to access expensive equipment to complete scientific endeavors and research projects. Disparities in funding across the nation and even within the same organization made it extremely difficult to purchase all the technologies needed. Two problems were identified: (1) there is an inability to identify ownership, location, and availability of scientific equipment; (2) even when identified, the dynamics of resource exchange and structuring formal and informal collaborations among the scientific community did not exist. Scien-up seeks to address these issues through their platform by offering a one-stop shop to both allocate and moderate scientific equipment sharing in Egypt and neighboring regions. Figure 3 presents Scien-up's sharing model for democratized access for scientific equipment. It aims to balance the under-utilized scientific equipment capacities through peer-to-peer exchange databases that allow scientists to share resources using an online platform.

\section{ANALYSIS OF EXEMPLARS}

All in all, the three examples provide different perspectives, and there are more, for degrowth. Table 1 relates the three urban Egypt technological innovation cases to degrowth dimensions and elements.

The examples can serve the same or even larger urban populations, with fewer resources (degrowth). The question does 
arise on whether there will be a rebound effect. Since the sharing and innovative technologies are so inexpensive, that communities will consume more and/or not pay attention to further resource reduction. That is always a concern, as well as feasibility of the solutions.

We acknowledge that the small examples shared in this paper, even with scalability will not guarantee degrowth, like they are unable to guarantee sustainability. However, it is something that provides ample opportunity to investigate. Our goal is to initiate the discourse on degrowth within environmental and social sustainability and encourage its inclusion on the map of policy makers.

\section{POLICY OPTIONS AND IMPLICATIONS}

There are many international development organizations and groups that can help support these efforts. Identifying, encouraging, and broadly supporting degrowth initiatives through programs and education is needed. In many governments, local, national, and international, as well as funding agencies, such as the World Bank and the International Monetary fund, the performance metrics for supporting economic development do not typically support degrowth and strong sustainability criteria. Although there are criteria for poverty alleviation and some sustainability; explicit consideration of various degrowth factors are not considered. Many of these organizations are oblivious to the potential of degrowth characteristics. Traditional measures that are based on economic growth are used to support various development programs; leaving degrowth options that may actually cause job losses, but improve living standards, by the wayside. These groups need to be educated on degrowth elements, priorities, and advantages. The co-benefits, such as poverty reduction, equity, and resource savings, can all be packaged within the degrowth narrative. Not only should they be concerned with innovation and improving marginalized populations, but also with building a strong sustainability setting. There needs to be a focused effort on measuring progress and gathering data. International development groups can help provide oversight and verification, giving international investors or benefactors more certainty that funds are supporting degrowth initiatives.

The innovations presented in the three cases have strong relationships with local universities. The United Nations supporting and partnering with universities in urban locations could be a way to encourage micro-innovation development. Currently, the United Nations has numerous programs that support various government initiatives, such as the Global Environment Facility. This group functions by providing grants to various regions of the world to conserve land and resources. Still problems related to access to finance and information awareness are hard to overcome. Smaller technological and entrepreneurial initiatives, especially those that support degrowth do not seem to be strongly motivated nor supported. Diffusion of these micro-innovations is also an important element that goes beyond the investment and funding stages. In Egypt there are small incubator labs, such as V$\mathrm{Lab}$ and the Research Institute for a Sustainable Environment (RISE), which can be used as small education centers and demonstration projects. Supporting these small non-profits, pseudo-government agencies, or University outreach centers can greatly enhance the infrastructure for the diffusion of these innovations.

These programs need flexibility and customization. An inward perspective focusing on encouraging local needs, resources, and solutions should be paramount. Although benchmarking and sharing is viable and useful, caution needs to be taken to make the necessary adjustments based on local conditions and culture. Whereas, water may be a major concern in Egypt's Cairo urban area; the concern may be less in cities where hazardous materials and waste are prominent. A typical criticism of using technological solutions, as discussed earlier, is the potential for rebound effects and capitalistic fervor that would cause greater inequity. Thus, policy makers and communities should keep a close eye on how to discern the unintended consequences of technology diffusion. For example relying on locally available resources may cause local resource scarcities. Vigilance and planning for these circumstances will be required by local communities and agencies.

\section{ACTIONABLE RECOMMENDATIONS}

We believe that supporting such frugal and micro-innovation ideas should be explicit in government policies. This would help to motivate entrepreneurs by creating the conditions under which such ideas could flourish:

- International organizations need to be educated about degrowth elements, priorities, and advantages as many of the international development organizations are oblivious to the potential of degrowth characteristics.

- Identifying, encouraging, and supporting these initiatives, through programs and formal education is needed.

- Developing smallholder innovation repositories amongst agencies and partnering of government with NGOs, private industry, and universities-a quadruple helix-can enhance diffusion.

- Sharing and benchmarking these ideas need to be completed broadly. There needs to be a focused effort on measuring progress and gathering data. International development groups can help provide oversight and verification, giving international investors or benefactors more certainty that funds are supporting degrowth initiatives.

- Developing performance metrics that specifically focus on degrowth is needed. The performance metrics for supporting economic development do not typically support degrowth and strong sustainability criteria.

\section{CONCLUSIONS}

Technological innovation does not necessarily mean the use of expensive software and hardware and complexity. 
Localized, inexpensive, democratizing technology can effectively support the degrowth paradigm; especially in developing nation-Global South-urban settings. Technological innovation should also take into consideration the culture and needs of local communities. These concepts are especially important in Global South urbanized areas. It is expected that these are the regions of the world that will be expected to grow the most and are vulnerable to sustainability challenges.

We provided three grassroots technological innovation examples from our research and experiences in Egypt's urban regions. While the examples are specific to Egypt, each of these technological innovations are portable to other regions. Degrowth is met through sufficiency, efficiency, democracy, ecosystems, and frugality. Overall, these initiatives use fewer materials and resources while providing service and needs for local populations. The building blocks example uses local material near the construction sites. So, building extra infrastructure and using resources for distant deliveries are lessened. There is less need for a construction infrastructure. The rooftop hydroponics use fewer resources in terms of materials, land, soil, and water. It also does not require a large infrastructure for trading food and products and results in less food waste. The final example of technology sharing requires

\section{REFERENCES}

Anderson, B. A. (2012). Testing the Effectiveness of Professional Development for Integrating Technology in an Urban Iowa Middle School. Northcentral University.

Anguelovski, I. (2014). "Urban gardening," In Degrowth: A Vocabulary for a New Era, eds G. D’Alisa, F. Demaria, and G. Kallis (New York, NY; London: Routledge), 192-194.

Attia, S. (2017). "Challenges of sustainable urban development and the phenomenon of densification in Cairo," in Revitalizing City Districts, The Urban Book Series, eds H. Abouelfadl, D. ElKerdany, and C. Wessling (Cham: Springer), 115-126. doi: 10.1007/978-3-319-46289-9_9

Batty, M. (2013). Big data, smart cities and city planning. Dialog. Hum. Geogr. 3, 274-279. doi: 10.1177/2043820613513390

Botsman, R., and Rogers, R. (2010). What's Mine is Yours-the Rise of Collaborative Consumption. New York, NY: HarperCollins.

Bregman, R. (2017). Utopia for Realists: And How We Can Get There. London: Bloomsbury Publishing.

Bunnell, T. (2015). Smart city returns. Dialog. Hum. Geogr. 5, 45-48. doi: $10.1177 / 2043820614565870$

Carvalho, L. (2014). Smart cities from scratch? A socio-technical perspective. Camb. J. Reg. Econ. Soc. 8, 43-60. doi: 10.1093/cjres/rsu010

Cattaneo, C., and Gavalda, M. (2010). The experience of rurban squats in Collserola, Barcelona: what kind of degrowth? J. Clean. Prod. 18, 581-589. doi: 10.1016/j.jclepro.2010.01.010

Dados, N., and Connell, R. (2012). The global south. Contexts 11, 12-13. doi: $10.1177 / 1536504212436479$

Domènech, L., March, H., and Saurí, D. (2013). Degrowth initiatives in the urban water sector? A social multi-criteria evaluation of non-conventional water alternatives in Metropolitan Barcelona. J. Clean. Prod. 38, 44-55. doi: 10.1016/j.jclepro.2011.09.020

Dorra, M. M., Farroh, H. E. S., and Amer, L. (2018). A proposal for desert house design in Egypt using passive ground cooling techniques. Renew. Energy Sustain. Dev. 4, 21-41. doi: 10.21622/resd.2018.04.1.021

Escobar, A. (2015). Critiques of Development. Degrowth: A Vocabulary for a New Era. London; New York, NY: Routledge. less building space and equipment, which can be large and use substantial materials.

These are all emergent ideas and their contributions to degrowth will need to be monitored. There are many other potential innovations in the Global South and in urban areas that exist. Sharing these innovations with other resources and capital deprived regions is needed. Some of these are hidden secrets and gems; some of them have been ignored due to a bias toward high revenue solutions evident in most of the Global North. It is not the next billionaire that will use and develop these initiatives, it is more likely to be your neighbor or community center.

Expanding the degrowth philosophy goes against many widely used economic goals; a major barrier to adopting technological innovations to support urban degrowth. The challenge is to support these initiatives through policy setting and expanding the idea that economic growth does not necessarily mean improved social and environmental situations.

\section{AUTHOR CONTRIBUTIONS}

SI and JS collectively developed the discussion of this policy brief. Examples were provided by SI. All authors contributed to the article and approved the submitted version.

Garcia, J. L., Jerónimo, H. M., and Carvalho, T. M. (2018). Methodological Luddism: a concept for tying degrowth to the assessment and regulation of technologies. J. Clean. Prod. 197, 1647-1653. doi: 10.1016/j.jclepro.2017.03.184

Gibbs, D., Krueger, R., and MacLeod, G. (2013). Grappling With Smart City Politics in an Era of Market Triumphalism. Newbury Park, CA: Sage.

Gouda, E. (2013). Urban Form Rehabilitation of the Informal Settlements in Egypt. Cairo: Al Azhar University.

Grunwald, A. (2018). Diverging pathways to overcoming the environmental crisis: a critique of eco-modernism from a technology assessment perspective. $J$. Clean. Prod. 197, 1854-1862. doi: 10.1016/j.jclepro.2016.07.212

Hobson, K. (2013). 'Weak'or 'strong'sustainable consumption? Efficiency, degrowth, and the 10 year framework of programmes. Environ. Plan. C Govern. Policy 31, 1082-1098. doi: 10.1068/c12279

Hobson, K. (2016). Closing the loop or squaring the circle? Locating generative spaces for the circular economy. Prog. Hum. Geogr. 40, 88-104. doi: 10.1177/0309132514566342

Hollands, R. G. (2015). Critical interventions into the corporate smart city. Camb. J. Reg. Econ. Soc. 8, 61-77. doi: 10.1093/cjres/rsu011

Illich, I. (1974). Energy and Equity, Vol. 6. New York, NY: Harper \& Row (1974).

Jarvis, H. (2019). Sharing, togetherness and intentional degrowth. Prog. Hum. Geogr. 43, 256-275. doi: 10.1177/0309132517746519

Kallis, G., Kostakis, V., Lange, S., Muraca, B., Paulson, S., and Schmelzer, M. (2018). Research on degrowth. Annu. Rev. Environ. Resour. 43, 291-316. doi: 10.1146/annurev-environ-102017-025941

Kerschner, C., and Ehlers, M. H. (2016). A framework of attitudes towards technology in theory and practice. Ecol. Econ. 126, 139-151. doi: 10.1016/j.ecolecon.2016.02.010

Kerschner, C., Waechter, P., Nierling, L., and Ehlers, M. H. (2018). Degrowth and technology: towards feasible, viable, appropriate and convivial imaginaries. J. Clean. Prod. 197, 1619-1636. doi: 10.1016/j.jclepro.2018.07.147

Krueger, R., Schulz, C., and Gibbs, D. C. (2018). Institutionalizing alternative economic spaces? An interpretivist perspective on diverse economies. Prog. Hum. Geogr. 42, 569-589. doi: 10.1177/0309132517694530

Kunze, C., and Becker, S. (2015). Collective ownership in renewable energy and opportunities for sustainable degrowth. Sustain. Sci. 10, 425-437. doi: $10.1007 / \mathrm{s} 11625-015-0301-0$ 
Latouche, S. (2009). Farewell to Growth. Cambridge, UK: Polity.

Lietaert, M. (2010). Cohousing's relevance to degrowth theories. J. Clean. Prod. 18, 576-580. doi: 10.1016/j.jclepro.2009.11.016

Likavčan, L., and Scholz-Wäckerle, M. (2018). Technology appropriation in a de-growing economy. J. Clean. Prod. 197, 1666-1675. doi: 10.1016/j.jclepro.2016.12.134

March, H. (2018). The Smart City and other ICT-led techno-imaginaries: any room for dialogue with degrowth? J. Clean. Prod. 197, 1694-1703. doi: 10.1016/j.jclepro.2016.09.154

Maritz, J. (2018). How We Made It in Africa: Learn From the Stories of 25 Entrepreneurs, Africa Business Insight. Cape Town: Maritz Africa.

Martin, C. J. (2016). The sharing economy: a pathway to sustainability or a nightmarish form of neoliberal capitalism? Ecol. Econ. 121, 149-159. doi: 10.1016/j.ecolecon.2015.11.027

Mason, P. (2016). Postcapitalism: A Guide to Our Future. New York, NY: Macmillan.

Nowak, M. (2004). Urban agriculture on the rooftop (Senior Honors thesis), Cornell University. Retrieved from: http://libarynth.org/_media/roofgarden_thesis.pdf

Perronnet, A., and Rodemeier, T. (2010). Imbaba Analysis. Basel: ETH Studio Basel Contemporary City Institute.

Pollio, A. (2016). Technologies of austerity urbanism: the "smart city" agenda in Italy (2011-2013). Urban Geogr. 37, 514-534. doi: 10.1080/02723638.2015.1118991

Price, L. (2013). Rooftop Agriculture Policy: An International Examination of Current Types, Instruments and Trends. Resource Efficiency in Architecture \& Planning. Hamburg: HafenCity University.

Quesnel, A. (2011). Solutions From Above: Using Rooftop Agriculture to Move Cities Towards Sustainability. Karlshamn: School of Engineering, Blekinge Institute of Technology.

Restrepo, J. D. C., and Morales-Pinzon, T. (2018). Urban metabolism and sustainability: precedents, genesis and research perspectives. Resour. Conserv. Recycl. 131, 216-224. doi: 10.1016/j.resconrec.2017.12.023

Romano, O. (2012). How to rebuild democracy, re-thinking degrowth. Futures 44, 582-589. doi: 10.1016/j.futures.2012.03.019

Rongbo, H. (2017). A Case Study on Regenerating Informal Settlements in Cairo Using Affordable and Adaptable Building System. Munich: Technical University of Munich.

Saleh, Y., and Ibrahim, S. E. (2018). Is the sharing economy a valid option for scientific research technologies in emerging economies? IEEE Eng. Manage. Rev. 46, 87-93. doi: 10.1109/EMR.2018.2863271

Satterthwite, D. (2011). Engaging With the Urban Poor and Their Organizations for Poverty Reductions and Urban Governance. An issue paper for the United Development Program. New York, NY: UNDP.

Schilling, M. A., and Shankar, R. (2019). Strategic Management of Technological Innovation. New York, NY: McGraw-Hill Education.
Schneider, F., Kallis, G., and Martinez-Alier, J. (2010). Crisis or opportunity? Economic degrowth for social equity and ecological sustainability. Introduction to this special issue. J. Clean. Prod. 18, 511-518. doi: 10.1016/j.jclepro.2010.01.014

Schröder, P., Bengtsson, M., Cohen, M., Dewick, P., Hoffstetter, J., and Sarkis, J. (2019). Degrowth within-aligning circular economy and strong sustainability narratives. Resour. Conserv. Recycl. 146, 190-191. doi: $10.1016 /$ j.resconrec.2019.03.038

Shelton, T., Zook, M., and Wiig, A. (2015). The 'actually existing smart city'. Camb. J. Reg. Econ. Soc. 8, 13-25. doi: 10.1093/cjres/rsu026

Smets, P., and van Lindert, P. (2016). Sustainable housing and the urban poor. Int. J. Urban Sustain. Dev. 8, 1-9. doi: 10.1080/19463138.2016.1168825

Smith, A., Fressoli, M., and Thomas, H. (2014). Grassroots innovation movements: challenges and contributions. J. Clean. Prod. 63, 114-124. doi: 10.1016/j.jclepro.2012.12.025

Spaargaren, G., and Mol, A. P. (1992). Sociology, environment, and modernity: ecological modernization as a theory of social change. Soc. Nat. Resour. 5, 323-344. doi: 10.1080/08941929209380797

Tawfic, A. (2016). Retrofitting green roofs to the urban morphology of informal settlements-introducing productive green roofs to Imbaba, Cairo (Master thesis), HafenCity University, Hamburg, Germany.

Tawfic, A., Ibrahim, S. E., and Sarkis, J. (2018). A Community Based Model for Rooftop Hydroponic Systems in Cairo Informal Settlements. Working paper. Available online at: https://www.emerald.com/insight/publication/issn/14777835

Ulgiati, S., and Zucaro, A. (2019). Challenges in urban metabolism: sustainability and well-being in cities. Front. Sustain. Cities 1:1. doi: 10.3389/frsc.2019. 00001

Viitanen, J., and Kingston, R. (2014). Smart cities and green growth: outsourcing democratic and environmental resilience to the global technology sector. Environ. Plan. A 46, 803-819. doi: 10.1068/a46242

Wiig, A. (2016). The empty rhetoric of the smart city: from digital inclusion to economic promotion in Philadelphia. Urban Geogr. 37, 535-553. doi: 10.1080/02723638.2015.1065686

Conflict of Interest: The authors declare that the research was conducted in the absence of any commercial or financial relationships that could be construed as a potential conflict of interest.

Copyright (๑) 2020 Ibrahim and Sarkis. This is an open-access article distributed under the terms of the Creative Commons Attribution License (CC BY). The use, distribution or reproduction in other forums is permitted, provided the original author(s) and the copyright owner(s) are credited and that the original publication in this journal is cited, in accordance with accepted academic practice. No use, distribution or reproduction is permitted which does not comply with these terms. 